\title{
Dendritic Cell-Idiotype-Keyhole Limpet Hemocyanin Vaccine
}

National Cancer Institute

\section{Source}

National Cancer Institute. Dendritic Cell-Idiotype-Keyhole Limpet Hemocyanin Vaccine.

NCI Thesaurus. Code C71760.

A cell-based vaccine composed of allogeneic dendritic cells (DC), pulsed with patientspecific non-Hodgkin's lymphoma idiotype (Id) determinants conjug ated to keyhole limpet hemocyanin $(\mathrm{KLH})$, with potential antitumor activity. Upon administration, this vaccine may stimulate the host immune system to mount a specific cytotoxic Tlymphocyte $(C T L)$ response against Id-expressing lymphoma cells, resulting in tumor cell lysis. 